Brit. J. industr. Med., 1963, 20, 313.

\title{
A FOLLOW-UP STUDY OF LEAD WORKERS
}

\author{
BY \\ I. DINGWALL-FORDYCE and R. E. LANE \\ From the Nuffield Department of Occupational Health, University of Manchester
}

(RECEIVED FOR PUBLICATION JUNE 12, 1963)

\begin{abstract}
Following the suggestion that lead derivatives might cause cancer in man, the causes of death among workers known to have been exposed to lead were studied. A group of companies made available the records of their pension fund, and an accumulator factory provided details of men who had died whilst in their employ. Details of each man's exposure to lead were supplied.

There were 425 pensioners, of whom 184 had died; 153 deaths occurred among an unknown number of employed men who had not yet reached pensionable age. Expected deaths were calculated from the appropriate rates for all males in England and Wales.

It was concluded that there was no evidence to suggest that malignant disease was related to lead absorption. There was, however, evidence that heavy exposure to lead was associated with an increased incidence of deaths from cerebrovascular catastrophies.
\end{abstract}

Zollinger (1953) described kidney tumours in rats following their long-term dosing with lead phosphate. A few years later this observation was confirmed by Mathews and Walpole (personal communication). Boyland, Dukes, Grover, and Mitchley (1962) fed 20 rats on a diet containing $1 \%$ lead acetate for one year. Of 16 which survived 320 days, 15 were found to have either adenomas or adenocarcinomas of the kidney. They suggested that the possibility that lead derivatives cause cancer in man should be examined.

Unfortunately current national figures are of little help in the examination of this problem. The mortality experiences of lead workers become swamped amongst those of men in allied trades which do not involve a lead hazard. Also the actual numbers involved are relatively small; during the five-year period 1949 to 1953 there were seven deaths attributed to malignant neoplasms among 1,200 lead burners, a figure which indicated a rather better mortality experience than that which occurred among the general population. In his decennial supplement of 1921 (Registrar-General, 1927) the RegistrarGeneral observed:-

\footnotetext{
"As it has recently been stated that lead confers such complete immunity from cancer that lead burners never die from this cause their record has been examined on this point and from such scanty data (as is available) the only certain conclusion to be drawn is that lead burners can die from cancer like other people."
}

A more satisfactory method of approach to the problem appeared to be a retrospective survey over many years of the fate of a group of workers known to have been exposed to lead. Such information could be obtained from a group of companies who readily made available the records of their pension fund. A large accumulator factory within the concern also provided details of men who had died whilst in their employ.

The companies concerned provided the details necessary to allocate each man to a category according to the degree of recognized lead hazard associated with the jobs he had held whilst in their employ. These were defined as follows:-Grade A, no exposure; grade B, negligible exposure, with lead-inurine values within the normal range; and grade $C$, exposure represented for the last 20 years by mean lead-in-urine values between 100 and $250 \mu \mathrm{g}$./1., but in the past these have not infrequently exceeded 250 $\mu \mathrm{g}$./l. Examples of the types of work in the various categories are shown in Table 1.

TABLE 1

GRADES OF EXPOSURE TO LEAD

\begin{tabular}{l|l|l}
\hline \multicolumn{1}{c|}{ A } & \multicolumn{1}{|c}{ B } & \multicolumn{1}{c}{ C } \\
\hline $\begin{array}{l}\text { General office } \\
\begin{array}{l}\text { Powemist } \\
\text { Stokers }\end{array}\end{array}$ & $\begin{array}{l}\text { Casting } \\
\text { General stores } \\
\text { Charging } \\
\text { Works department } \\
\text { office }\end{array}$ & $\begin{array}{l}\text { Assembly Plate cutting } \\
\text { Porming Pasting and mixing } \\
\text { Plumbers Lead recovery } \\
\text { Packers Tube filling }\end{array}$ \\
\hline
\end{tabular}

313 


\section{Pensioners}

This population comprised all men who became pensioners between the years 1926 and 1960 . In order to be eligible for a pension a man must have reached 65 years of age and have not had less than 25 years' service. Arrangements can be made for an earlier retirement but this is very infrequent, and years of service and age must total at least 95 .

There were 425 pensioners, of whom 184 had died during the period under review. Details of grade and length of service are shown in Table 2.

TABLE 2

MEN BECOMING ELIGIBLE FOR A PENSION, 1926-1960

\begin{tabular}{l|l|l|l}
\hline & \multicolumn{3}{|c}{ Grade of Exposure } \\
\cline { 2 - 3 } & A & B & C \\
\hline No. of men & 158 & 80 & 187 \\
Mean exposure (yr.) & $\frac{35 \cdot 3}{36}$ & 27 & $32 \cdot 3$ \\
No. of deaths & 101 \\
\hline
\end{tabular}

Causes of death were obtained from the death certificates. Death rates for all males in England and Wales were extracted from the Registrar General's Statistical Reviews (1933, 1938, 1943, 1948, 1953 and 1958). The number of "expected" deaths among the pensioners was calculated from the populations at risk, assuming that they had had the same mortality experience, standardized for age, as that of all males.

\section{Deaths whilst in Employment}

An examination was made of the deaths of all men who had died between 1946 and 1961 whilst employed by the electric accumulator company (Table 3 ).

TABLE 3

MEN DYING DURING THE PERIOD 1946-1961 WHILST IN EMPLOYMENT

\begin{tabular}{l|c|c|c}
\hline & \multicolumn{2}{|c}{ Grade of Exposure } \\
\cline { 2 - 3 } & A & B & C \\
\hline No. of men & 35 & 40 \\
Mean exposure (yr.) & $\frac{57.7}{57.7}$ & 53.4 & 78 \\
Mean age & 21.8 \\
\hline
\end{tabular}

There were 153 such deaths, the causes of which were taken from the death certificates.

The actual population at risk was not known for this group. "Expected" deaths were therefore based on the ratios of numbers from specific causes to numbers from all causes found amongst all males in England and Wales. These were calculated in fiveyear age groups from 35 to 70 for the years 1948,1953 , and 1958.

\section{Results}

Deaths from all Causes.-Evidence of an excess, or a deficit, of deaths from all causes could only be sought among the pensioners.

The results were examined according to grades and date of death. There was found to be a significant excess in grade $\mathrm{C}(p<0.01)$. Details are shown in Table 4.

Deaths from Malignant Neoplasms, All Sites.Deaths from malignant neoplasms were examined according to grade and date of death. In grade B there was an increase in observed deaths among both pensioners and employed men (Table 5). The differences, although not significant in either group alone, were possibly significant when combined $(p<0.05$, $\mathrm{n}=2, x^{2}=7 \cdot 5$ ).

However, in grade $C$, the most heavily exposed grade, there was no evidence of any excess of deaths among either pensioners or employed men.

Thus the excess of deaths from all causes could not be attributed to malignant neoplasms.

Deaths from Cerebral Haemorrhage, Cerebral Thrombosis, and Cerebral Arteriosclerosis.-There appeared to have been a relatively large number of deaths attributed to vascular lesions affecting the central nervous system. Deaths from cerebral catastrophies were therefore examined (Table 6) and were found to be in excess to a highly significant extent $(p<0.001)$ among grade $C$ pensioners.

Although the numbers involved are small, it may be noted that the ratio of observed to expected deaths increased with exposure in both groups; also

TABLE 4

EXPECTED AND OBSERVED DEATHS FROM ALL CAUSES IN PENSIONERS, 1926-1961

\begin{tabular}{|c|c|c|c|c|c|c|c|}
\hline \multirow{3}{*}{ Year of Death } & \multicolumn{6}{|c|}{ Grade of Exposure } & \\
\hline & \multicolumn{2}{|c|}{$\mathbf{A}$} & \multicolumn{2}{|c|}{$\mathbf{B}$} & \multicolumn{2}{|c|}{$\mathbf{C}$} & \\
\hline & Expected & Observed & Expected & Observed & Expected & Observed & \\
\hline $\begin{array}{l}1926-1940 \\
1941-1950 \\
1951-1961 \\
1926-1961\end{array}$ & $\begin{array}{r}6.0 \\
9.6 \\
51.2 \\
66.8\end{array}$ & $\begin{array}{r}4 \\
14 \\
38 \\
56\end{array}$ & $\begin{array}{r}0.4 \\
2 \cdot 3 \\
22 \cdot 6 \\
25 \cdot 3\end{array}$ & $\begin{array}{r}1 \\
6 \\
20 \\
27\end{array}$ & $\begin{array}{r}3.6 \\
11.2 \\
60.2 \\
75.0\end{array}$ & $\begin{array}{c}5 \\
16 \\
80^{*} \\
101^{*}\end{array}$ & $\begin{array}{l}x^{2}=6.5 \\
x^{2}=9.0\end{array}$ \\
\hline
\end{tabular}

$* p<0.01$ 
TABLE 5

EXPECTED AND OBSERVED DEATHS FROM MALIGNANT NEOPLASMS IN PENSIONERS, 1926-1961, AND IN EMPLOYED MEN, 1946-1961

\begin{tabular}{|c|c|c|c|c|c|c|c|}
\hline & \multirow{3}{*}{ Year of Death } & \multicolumn{6}{|c|}{ Grade of Exposure } \\
\hline & & \multicolumn{2}{|c|}{$\mathbf{A}$} & \multicolumn{2}{|c|}{ B } & \multicolumn{2}{|c|}{ C } \\
\hline & & Expected & Observed & Expected & Observed & Expected & Observed \\
\hline \multirow[t]{2}{*}{ Pensioners } & $\begin{array}{l}1926-1940 \\
1941-1950 \\
1951-1961\end{array}$ & $\begin{array}{l}0.9 \\
1.7 \\
8.7\end{array}$ & $\begin{array}{l}2 \\
3 \\
9\end{array}$ & $\begin{array}{l}0 \cdot 1 \\
0 \cdot 5 \\
4 \cdot 1\end{array}$ & $\begin{array}{r}0 \\
0 \\
10\end{array}$ & $\begin{array}{r}0.6 \\
1.9 \\
10.0\end{array}$ & $\begin{array}{l}0 \\
1 \\
9\end{array}$ \\
\hline & $1926-1961$ & $11 \cdot 3$ & 14 & $4 \cdot 7$ & 10 & $12 \cdot 5$ & 10 \\
\hline Employed & $1946-1961$ & $8 \cdot 8$ & 10 & $9 \cdot 5$ & 15 & $18 \cdot 5$ & 17 \\
\hline
\end{tabular}

TABLE 6

EXPECTED AND OBSERVED DEATHS FROM CEREBRAL HAEMORRHAGE, CEREBRAL THROMBOSIS, AND CEREBRAL ARTERIOSCLEROSIS IN PENSIONERS, 1926-1961, AND IN EMPLOYED MEN, 1946-1961

\begin{tabular}{|c|c|c|c|c|c|c|c|c|}
\hline & \multirow{3}{*}{ Year of Death } & \multicolumn{6}{|c|}{ Grade of Exposure } & \\
\hline & & \multicolumn{2}{|c|}{$\mathbf{A}$} & \multicolumn{2}{|c|}{ B } & \multicolumn{2}{|c|}{ C } & \\
\hline & & Expected & Observed & Expected & Observed & Expected & Observed & \\
\hline \multirow[t]{2}{*}{ Pensioners } & $\begin{array}{l}1926-1950 \\
1951-1961\end{array}$ & $\begin{array}{l}0.7 \\
7.2\end{array}$ & $\begin{array}{l}0 \\
6\end{array}$ & $\begin{array}{l}0 \cdot 2 \\
3 \cdot 2\end{array}$ & $\begin{array}{l}3 \\
3\end{array}$ & $\begin{array}{l}0.8 \\
8.5\end{array}$ & $\begin{array}{r}5 \\
19\end{array}$ & \\
\hline & $1926-1961$ & 7.9 & 6 & $3 \cdot 4$ & 6 & $9 \cdot 3$ & $24^{*}$ & $x^{2}=21 \cdot 7$ \\
\hline Employed & $1946-1961$ & $3 \cdot 2$ & 3 & $3 \cdot 1$ & 3 & 5.6 & 9 & \\
\hline
\end{tabular}

* $p<0.001$

the increase was most marked amongst the earliest deaths. This indication of a possible correlation between these deaths and the degree of lead hazard is in complete contrast to the pattern shown by deaths due to malignant neoplasms.

In 1921 cerebral haemorrhage was the cause of a significant excess of deaths amongst plumbers, painters, and decorators (Registrar-General, 1927). Amongst the small numbers of lead burners there were during 1930-1932 three such deaths to one "expected", and during 1949-1953 four deaths to two "expected" (Registrar-General, 1938 and 1957).

\section{Discussion and Conclusions}

There was found to be a significant excess of deaths from all causes amongst those pensioners who had been exposed to the greatest lead hazard. This excess could not be attributed to malignant neoplasms as the number of deaths from this cause was found to be slightly less than expected among these heavily exposed men.

Although there was an excess of deaths from malignant neoplasms among the men with slight lead exposure, the increase was only apparent in the last decade.

Thus the incidence of malignant disease is least among the men engaged on the most hazardous processes and has become greater as the exposure to lead has become less following improvements in factory conditions. It is concluded therefore that malignant disease is not related to lead absorption.
The pattern of deaths from vascular lesions of the central nervous system is markedly different. Deaths from these causes are very significantly in excess in the groups most heavily exposed to lead. Analysis has shown, moreover, that, as exposure has decreased with improved working conditions, the excess of central nervous system vascular lesions has diminished. It appears therefore that men who were exposed to a lead hazard during the first quarter of this century may have had their lives shortened. Cerebral haemorrhage in later life has been shown to occur more frequently amongst them than in the general population. There are, however, indications which suggest that the danger may by now have been reduced.

We wish to thank the Chloride Electric Storage Company for allowing access to their records and for financial assistance; Dr. D. Malcolm for providing details of those who died in service; and those members of the staff of the various associated companies who provided detailed information regarding lead exposure.

\section{REFERENCES}

Boyland, E., Dukes, C. E., Grover, P. L., and Mitchley, B. C. Y. (1962). Brit. J. Cancer, 16, 283.

The Registrar-General (1927). Decennial Supplement, England and Wales. 1921.

The Registrar-General (1938). Decennial Supplement, England and Wales. 1931.

The Registrar-General (1957). Decennial Supplement, England and Wales. 1951 .

The Registrar General's Statistical Review of England and Wales, Part 1. 1933, 1938, 1943, 1948, 1953, 1958.

Zollinger, H. U. (1953). Virchows Arch. path. Anat., 323, 694. 